\title{
Rice Productivity Growth During Nine Years in Badung Regency, Bali Province
}

\author{
Anak Agung Keswari Krisnandika1 ${ }^{*}$, I Made Anom Sutrisna Wijaya1, I Gusti Agung \\ Ayu Ambarawati', Anak Agung Ayu Mirah Adi', Eisaku Tamura'2, Chiharu Hongo ${ }^{2}$ \\ ${ }^{1}$ Center on Food Availability for Sustainable Improvement, Udayana University, Bali, Indonesia \\ 2 Center for Environmental Remote Sensing, Chiba University, Chiba, Japan \\ *Corresponding author's e-mail:agung_keswari@unud.ac.id
}

\begin{abstract}
How to Cite: Krisnandika, A.A.K., Wijaya, I.M.A.S., Ambarawati, I.G.A.A., Adi, A.A.A.M., Tamura, E., and Hongo, S. (2019). Rice productivity growth during nine years in Badung Regency, Bali Province. Int. J. Agr. Syst. 7(2): 106-115
\end{abstract}

\begin{abstract}
The trend of rice productivity and its stability in Badung Regency are presented in this study. The area is a tourism-based economy without leaving the role of rice production to feed the people. Time series data were collected from five sub districts covering 53 villages during 2008-2016 due to the completeness of the data. Variability of the data was observed from the coefficient of variance (C.V.) to decide rice productivity stability. This study also observed correlation between rainfall and rice productivity in the area. Result of the study shows that rice productivity trend in Badung Regency tend to decline during nine years of observation especially in 2014-2016. Three sub-districts had stable condition, while two sub-districts in tourism area contributed to the decline of this matter. Analysis using bi-plot revealed that there is no significant correlation between rainfall in sub-district and rice productivity, implying that water is available throughout the year. In terms of stability, majority of villages $(69.81 \%)$ had stable condition of rice productivity ranging from middle and high category. Other $30.19 \%$ villages were categorized as unstable ranging from low to high productivity. This condition showed that Badung Regency were able to maintain stability of rice productivity during nine years of observation. Implication of this study is to pay more attention to two sub districts in tourism area to improve their rice productivity such as implementation of good agricultural practices.
\end{abstract}

Copyright $\odot 2019$ IJAS. All rights reserved.

Keywords:

rice productivity; rice stability; Badung regency

\section{Introduction}

Rice is still the staple food in Indonesia, it is seen from the annual average requirement of rice per capita of Indonesian's people reaching $163 \mathrm{~kg}$ during 2012-2014. This figure is ranked $3^{\text {rd }}$ after Vietnam and Bangladesh (FAO, 2015). Meanwhile, the average annual rice production in Indonesia is 70498020 tons (Kementerian Pertanian, 2015) with a population of 237641326 inhabitants based on the 2010 census of population. The estimated population increase of 270538.4 people by 2025 will cause increase in rice consumption. Increasing the need for rice without the accompanying increase in rice production is a distinct threat to national food security in Indonesia. 
Bali is an area with high productivity of paddy after West Java and East Java which is 5.88 tons hectare ${ }^{-1}$ based on 2011-2015 average data (Kementerian Pertanian, 2015). With a relatively low harvest area compared to other regions in Indonesia, Bali is still able to meet the needs of rice (self-sufficiency) and can contribute about $1.23 \%$ to the national rice production. However, the increasing rate of Bali's population will be accompanied by an increase in rice demand in Bali. The future challenge faced is how to increase rice production in the midst of limited agricultural land. Badung Regency is one region in the province of Bali which has the highest population growth rate of $2.21 \%$ in 2015-2016 (BPS-Statistic of Bali Province, 2017) with population densities reaching 1505 in every km2 (BPS-Statistic of Badung Regency, 2017). Thus, to meet the demand for rice in this region, evolving the harvest area for increasing rice production is almost absurd. Increasing productivity is one of the most feasible ways to be established now days.

Rice productivity is the result of the interaction of genetic, environmental and human factors. This has led to the need to address specific location of rice production issues to achieve optimum productivity and stability. Before planning any specific location strategy, the trend of rice productivity from previous years in areas producing rice in Badung Regency needs to be studied first. Based on those trends it can be analyzed the yield stability in every production area. This study is important to find out which areas of which productivity can still be improved and need to manage. The area with unstable yield needs more attention and treatment than of the stable area. In previous research, analysis of rice productivity using secondary data from year to year has been done in some areas such as Myanmar, India, Nigeria, Malaysia (Denning et al., 2013; Tripathi et al., 2014; Mundhe, 2015; Adedeji and Owolabi, 2016; Merem et al., 2017; Ismail and Ngadiman, 2017). In general, the purpose of those study is for forecasting, mapping or as an input for policy decision.

One way to evaluate stability of rice productivity is using the yield variations data per year (Roel and Plant, 2004). In China, Chen et al. (2015) used coefficient of variations (C. V.) to measure rice yield stability. Another study from Ray et al. (2014) also shown the C.V. analysis to evaluate yield variability in worldwide. There are several previous studies related to rice production in Bali-Indonesia, for example that has been done by Panuju et al. (2012) and also Ustriyana (2015), unfortunately, there has been no report related to analysis of rice productivity trends using C.V. in Badung Regency. Therefore, the primary goal of this study was to evaluate the rice productivity trend and stability in Badung Regency of Bali Province. This would lead to a better understanding of complexities in the rice production as required of improved policy analysis. Both environment and human aspects are discussed in following subsections.

\section{Materials and Methods}

\subsection{Study area}

Study area in this research is located in Badung Regency of Bali Province of Indonesia which is reside at $8014^{\prime} 20^{\prime \prime}-8050^{\prime} 52^{\prime \prime}$ south latitude and $115055^{\prime} 03^{\prime \prime}-115026^{\prime} 51^{\prime \prime}$ east longitude with height of sea level 0-2 075 meters. Badung has a tropical climate with temperature ranged between $22-34^{\circ} \mathrm{C}$ during 2008-2016. Badung Regency has an area of $418.52 \mathrm{~km} 2$ consisting of six Sub-districts and 62 villages but only five Sub-districts with a total of 53 villages that produce rice consistently. The total area of rice fields in 2016 is 9975.7 hectares (BPS-Statistic of Badung Regency, 2017). 


\subsection{Data source}

All data used in this study were obtained from the Indonesian Central Bureau of Statistics, including data on rice production, rainfall data and temperature. The data were collected from five Sub-districts in Badung Regency during the year 2000-2016, due to the completeness of the data, this study used data from 2008-2016.

\subsection{Statistical data analysis}

Production data and harvested area from 2008-2016 were inputted into Microsoft Excel for subsequently calculated its productivity per year using formula:

Rice Productivity $=$ rice production (tons) $:$ harvest area (ha)

Productivity data (1) obtained then normalized to reduce data complexity using the formula as follows:

Normalized data $=\left(x_{i}-\overline{x_{\imath}}\right) * 100 \%$

Variability data can be evaluated through its coefficient of variance (C.V.), where the greater the C.V. the data becomes heterogeneous. C.V. is obtained by dividing standard deviation $(\mathrm{Si})$ with the mean of those normalized data (2) then multiplied by $100 \%$, whereby:

$$
\text { Si }=\sqrt{\sum\left(x_{i}-\overline{x_{i}}\right)^{2} /(n-1)}
$$

Where $\bar{x}_{\imath}$ is the average of rice productivity in village $i(i=1,2,3, \ldots .53)$

$x_{i}$ is rice productivity in village $\mathrm{i}$

$\mathrm{n}$ is the sampled sized of $x_{i}$

\section{Results and Discussion}

\subsection{Rice Productivity Trend in Badung Regency}

In general, rice productivity trend in Badung Regency has decreased especially in 20142016, which reached 12\% (Figure 1a). The decrease of rice productivity in Badung Regency seems to be caused by the decrease of productivity in some Sub-districts in Badung Regency, especially North Kuta and Kuta which decreased drastically after 2014 which is $26.59 \%$ and $28.94 \%$ (Figure 1b.). Mengwi and Abiansemal Sub-districts have the same productivity trend and tend to be stable compared to 3 other districts with productivity in the range of 6 tons hectare ${ }^{-1}$. While, Petang Sub-district has productivity trend which tends to be stable at 5.5 tons hectare-1. 


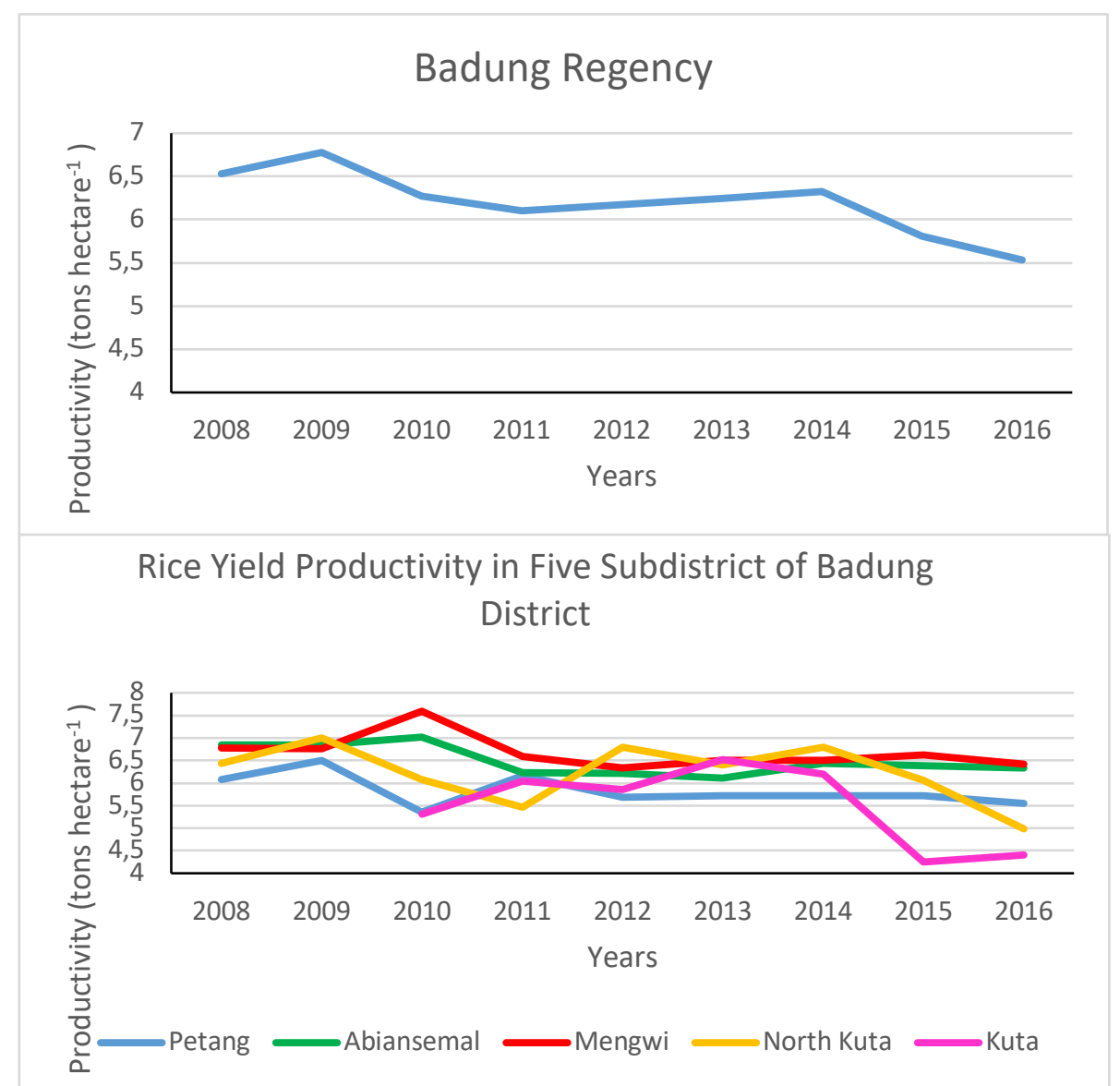

Figure 1. Rice productivity trend over 9 years in Badung Regency (a) and Sub-district (b) Note: Kuta Sub-district rice productivity in 2008-2009 are missing.

Rainfall relationship with water availability may be one of the factors that can affect rice productivity in Badung regency. However, the result of analysis using biplot shows there is no significant correlation between rainfall in every sub-district with rice productivity nor rainfall and rice productivity per year (Figure 2.).

Figure 2. Biplot of productivity and rainfall by Sub-district (a); years (b) in Badung Regency 
Productivity data for each regency and sub-district cannot be separated from the productivity per village. The existence of productivity instability in some sub-districts in Badung Regency indicates an instability of productivity in the village. To find out more detail about the instability of productivity in Badung Regency, it is necessary to analyze the stability of productivity per village. Furthermore, it is necessary to group the area based on the productivity of each village to know which village needs to improve.

\subsection{Yield stability and productivity}

The analysis then proceeded to the productivity of rice per village in five Sub-districts in Badung Regency for 9 years which then compared with the average of national rice productivity in Indonesia. The national rice productivity in Indonesia lies between 5.5-6.5 tons hectare ${ }^{-1}$, therefore, rice productivity above 6.5 tons hectare $^{-1}$ is classified as high productivity areas. While villages with productivity below 5.5 tons hectare ${ }^{-1}$ are classified into low-productivity villages. The results showed that of 53 villages in Badung Regency, 26 villages $(49.06 \%)$ had high productivity, 25 other villages $(47.17 \%)$ were in the middle and the remaining 2 villages $(3.78 \%)$ had low productivity (Table 1). Yield stability area in Badung Regency can be seen from the C.V. of productivity, where the greater the C.V. then the higher diversity between the data, which means the more unstable and vice versa.

The result of C.V. rice productivity from 2008-2016 shows the average C. V. of Badung Regency is $9.70 \%$. This C.V. is then used as the standard for determining the yield stability of villages in Badung Regency. The results showed that 37 out of 53 villages observed $(69.81 \%)$, having C. V. below the average (Table 1). This reveals that the majority of villages in Badung Regency had stable condition of rice productivity ranging from middle and high during nine years of observation. This condition showed that Badung Regency to some extent were able to maintain stability of rice production. Meanwhile, the rest of 16 villages (30.29\%) were categorized as unstable ranging from high to low productivity class. They were scattered in all Sub-districts from north to south (Figure 3). This shows that 16 villages in Badung Regency experienced high inter-year productivity fluctuations.

Tabel 1. Yield stability and productivity class

\begin{tabular}{cccccc}
\hline $\begin{array}{c}\text { Yield } \\
\text { Stability }\end{array}$ & Subdistrict & Village & $\mathbf{C V}(\%)$ & $\begin{array}{c}\text { Yield } \\
\text { (Ton/Ha) }\end{array}$ & $\begin{array}{c}\text { Productivity } \\
\text { Class }\end{array}$ \\
\hline \multirow{6}{*}{ Stable } & Mengwi & Kapal & 7.40 & 7.02 & high \\
& Mengwi & Munggu & 5.13 & 6.99 & high \\
& Mengwi & Penarungan & 7.27 & 6.95 & high \\
& Mengwi & Mengwitani & 5.13 & 6.9 & high \\
& Mengwi & Cemagi & 5.82 & 6.89 & high \\
& Mengwi & Buduk & 5.48 & 6.85 & high \\
& Petang & Petang & 6.24 & 6.83 & high \\
& Mengwi & Mengwi & 5.65 & 6.80 & high \\
& Mengwi & Baha & 7.57 & 6.79 & high \\
& Mengwi & Gulingan & 5.46 & 6.77 & high \\
& Mengwi & Sading & 5.65 & 6.75 & high \\
& Mengwi & Lukluk & 7.11 & 6.70 & high
\end{tabular}




\begin{tabular}{|c|c|c|c|c|c|}
\hline & Mengwi & Pererenan & 8.43 & 6.65 & high \\
\hline & Mengwi & Sempidi & 7.14 & 6.65 & high \\
\hline & Abiansemal & Bongkasa Pertiwi & 5.09 & 6.58 & high \\
\hline & Abiansemal & Taman & 5.12 & 6.56 & high \\
\hline & Abiansemal & Darmasaba & 4.91 & 6.56 & high \\
\hline & Abiansemal & Sangeh & 4.76 & 6.54 & high \\
\hline & Abiansemal & Bongkasa & 5.65 & 6.53 & high \\
\hline & Petang & Pangsan & 4.67 & 6.52 & high \\
\hline & Abiansemal & Selat & 5.64 & 6.51 & high \\
\hline & Abiansemal & Sedang & 5.43 & 6.51 & high \\
\hline & Abiansemal & Dauh Yeh Cani & 5.56 & 6.49 & middle \\
\hline & Abiansemal & Sibang Kaja & 5.10 & 6.49 & middle \\
\hline & Abiansemal & Punggul & 5.03 & 6.49 & middle \\
\hline & Abiansemal & Ayunan & 6.30 & 6.44 & middle \\
\hline & Abiansemal & Sibang Gede & 7.05 & 6.41 & middle \\
\hline & Abiansemal & Jagapati & 6.10 & 6.41 & middle \\
\hline & North Kuta & Dalung & 8.54 & 6.40 & middle \\
\hline & North Kuta & Kerobokan Kaja & 8.31 & 6.39 & middle \\
\hline & North Kuta & Tibubeneng & 8.56 & 6.39 & middle \\
\hline & Abiansemal & Angantaka & 7.31 & 6.39 & middle \\
\hline & Abiansemal & Blahkiuh & 7.96 & 6.38 & middle \\
\hline & Abiansemal & Abiansemal & 7.17 & 6.37 & middle \\
\hline & Petang & Getasan & 4.80 & 5.99 & middle \\
\hline & Petang & Belok & 4.87 & 5.97 & middle \\
\hline & Petang & Carangsari & 6.00 & 5.82 & middle \\
\hline \multirow{16}{*}{ Unstable } & Mengwi & Kekeran & 19.55 & 7.41 & high \\
\hline & Abiansemal & Mambal & 11.22 & 6.83 & high \\
\hline & North Kuta & Canggu & 12.17 & 6.79 & high \\
\hline & Mengwi & Werdi bhuana & 9.12 & 6.52 & high \\
\hline & Mengwi & Tumbakbayuh & 13.84 & 6.30 & middle \\
\hline & Abiansemal & Mekar Bhuana & 9.11 & 6.29 & middle \\
\hline & Mengwi & Abianbase & 13.15 & 6.25 & middle \\
\hline & Mengwi & Sobangan & 12.26 & 6.23 & middle \\
\hline & Mengwi & Sembung & 9.88 & 6.18 & middle \\
\hline & Mengwi & Kuwum & 15.15 & 5.92 & middle \\
\hline & Petang & Pelaga & 13.34 & 5.74 & middle \\
\hline & Kuta & Seminyak & 23.02 & 5.72 & middle \\
\hline & North Kuta & Kerobokan Kelod & 33.47 & 5.68 & middle \\
\hline & North Kuta & Kerobokan & 38.73 & 5.66 & middle \\
\hline & Kuta & Kuta & 16.13 & 5.30 & low \\
\hline & Petang & Sulangai & 34.36 & 3.92 & low \\
\hline
\end{tabular}


The combination of yield stability and productivity class can be seen in Table 1 and Figure 3. Of the 20 villages in the Mengwi Sub-districts that produce paddy, $65 \%$ of them have high productivity and stable, $10 \%$ of high is unstable, while the remaining $25 \%$ has productivity of 5.5-6.5 tons hectare- 1 but unstable. For Abiansemal Subdistrict, $88.80 \%$ of the 18 villages have stable productivity which is $38.8 \%$ high productivity and the rest $50 \%$ have middle productivity, while $11.12 \%$ of villages in this Sub-district have unstable productivity $5.56 \%$ high productivity and the rest of moderate productivity. North Kuta Sub-district consists of 6 villages where $50 \%$ of its villages have moderately stable productivity, while the remaining $50 \%$ is unstable with high productivity of $16.67 \%$ and moderate productivity is $33.33 \%$. Petang Subdistrict has 7 villages producing continuous rice, of which $71.43 \%$ of the area has a stable productivity of $28.57 \%$ high productivity and $42.86 \%$ of middle productivity, while 28.57 unstable area consists of $14.29 \%$ of medium productivity villages and $14.29 \%$ low productivity. Meanwhile, Kuta Sub-district only has 2 villages producing rice, namely Seminyak and Kuta villages, both villages have unstable productivity which is medium and low.
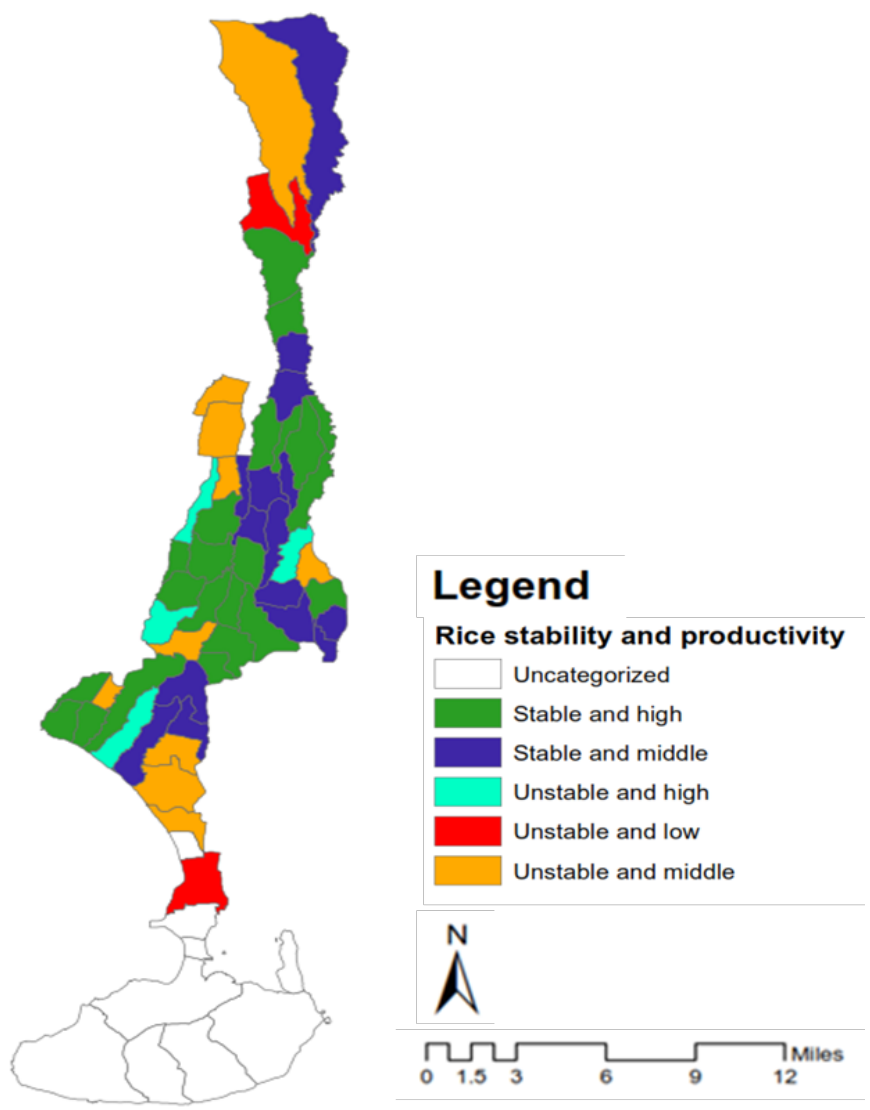

Figure 3. Rice stability and productivity in Badung Regency from 2008-2016

\subsection{Discussion}

Variability of rice productivity is influenced by genetic, human and environmental factors such as climate (Edeh et al., 2011; Takama et al., 2014; Singha et al., 2017), soil fertility (Wassmann et al., 2009; Talpur et al., 2013), water availability (Panuju et al., 2012) and disaster (diseases, pest, drought or flood) (Bappeda Litbang Kabupaten 
Badung, 2014). Rainfall intensity and duration reported by Edeh et al. (2011) can have a significant effect on rice yield variability in Ebonyi State. Moreover, Subash and Gangwar (2014) report that monsoon rainfall contributes $48 \%$ variation in rice productivity over India. This study attemped to correlate between rice productivity and the average of rainfall in Badung regency. Results from the biplot analysis show that there is no significant correlation between rice productivity and rainfall (Figure 2). This may be due to farmers in Badung Regency do not fully rely on rainfall in rice farming. Rice production system in Bali including Badung Regency is organized under the farming system called subak. Subak is a socio-religious water management system to arrange water availability during planting season under agreement of farmer members. In the subak system, it is allowed to take turn water for subak members who need water in time of planting and maintenace. It is expected there is no water shortage for farmers who need water for certain stage of paddy growth. Based on Ministry of Public Works (2016), water availability in Badung regency is supported by two watersheds namely Ayung and Penet to provide water along the year.

Sulangai Village (Petang Sub-district) and Kuta Village (Kuta Sub-district) are the only villages that have low productivity in Badung Regency. Both villages also have a large C.V., which means that the fluctuation of annual productivity data in this village is very high. This indicates that both villages still have the potential to improve productivity and stability through good farming management, especially in terms of factors causing low rice production. Panuju et al. (2012) stated that farming management is important in order to improve rice productivity. Sulangai village is known to have a steep topography that is prone to landslides during high rainfall intensity, landslide disaster that can cause rice harvest failure in this village. In addition, according to Suarja (2015) the drought that resulted in the delay of planting until rice harvest failure occurred in this area because most farmers $(80 \%)$ have not implemented micro-watershed technology (terracing, rorak, biopori, absorption wells, rainwater drum collection) to harvest rain water. Farmers still rely on irrigation channels. Meanwhile, the irrigation channel still needs to be upgraded to be able to irrigate the entire rice production area in Sulangai village. Decreased water discharge due to reduced forest vegetation cover, river border and springs in Ayung Watershed also become the factor causing drought in this village. Kuta village, on the other hand, is in the tourism area, where agriculture is not an interesting activity especially for the younger generation in this region. Agricultural labor availability may contribute to the reasons for low productivity of rice in this area. Conflict of interest in the use of water for agriculture and non-agriculture like in Kuta village may also be a factor that causes low rice productivity. Accordingly, in addition to the construction and repair of drainage channels, good agricultural practices by farmers need to be implemented in order to increase productivity.

The educational factors such as knowledge of good agricultural practices given to farmers seem to be one effective way of increasing rice productivity. Research conducted by Takama and Adrian (2014) shows that farmers who have been trained by extension workers can increase their productivity up to $12 \%$ when compared to farmers who do not attend training. Suharyanto et al. (2015) reported that farmers who have been trained can understand the importance of certified seed and appropriate input management to improve and maintain rice productivity stability and apply it in their rice cultivation. The application includes using certified rice seeds 
with legowo planting system accompanied by controlled use of fertilizers and pesticides as well as irrigation management according to the rice growth phase.

\section{Conclusion}

Result of the study found that the majority of villages (69.81\%) in Badung Regency had stable condition of rice productivity ranging from middle and high during nine years of observation. This condition showed that Badung Regency to some extent were able to maintain stability of rice production. Meanwhile, the rest of $30.29 \%$ villages were categorized as unstable ranging from high to low productivity class. Two villages (Sulangai and Kuta) even have rice productivity below than the national average. These villages need to be given more attention to improve their productivity. The study also found that there is no significant correlation between rice productivity and rainfall in Badung regency. This study implies other factors need to be considered to improve rice productivity such as good agricultural practices.

\section{Acknowledgements}

This study was supported by CEReS (Center for Environmental Remote Sensing), Chiba University, Japan under the project Overseas Joint Research Program 2017.

\section{References}

Adedeji, I. A. and J. O. Owolabi. (2016). Growth Trend Analysis of Rice Productivity in Nigeria. Agroeconomia Croatica 6(1):25-37.

Bappeda Litbang Kabupaten Badung. (2014). Rencana Kerja Pembangunan Daerah (RKPD) Kabupaten Badung Tahun 2015. Pemerintah Kabupaten Badung.

BPS-Statistic of Badung Regency. (2017). Badung Regency in Figures 2017. BPS Statistic of Badung Regency.

BPS-Statistic of Bali Province. (2017). Bali Province in Figures 2017. BPS Statistics of Bali Province.

Chen, Q., J. Zhang and L. Zhang. (2015). Risk Assessment, Partition and Economic Loss Estimation of Rice Production in China. Sustainability (7):563-583.

Denning, G., K. Baroang and T. M. Sandar. (2013). Background Paper No.2. Rice Productivity Improvement in Myanmar. Available online at: https://www.themimu.info/sites/themimu.info/files/documents/Ref_Doc_Background_Pa per_2_Rice_Productivity_Improvement_Mar2013.pdf (accessed 5 April 2017).

Edeh, H. O., E. C. Eboh and B. N. Mbam. (2011). Analysis of Environmental Risk Factors Affecting Rice

FAO. (2015). OECD-FAO Agricultural Outlook. Available online at: $\underline{\text { ttps: } / / \text { read.oecd- }}$ ilibrary.org/agriculture-and-food/oecd-fao-agricultural-outlook-2015/rice-projectionsconsumption-per-capita_agr_outlook-2015-table125-en\#page1 (accessed 5 April 2017).

Farming in Ebonyi State, Southeastern Nigeria. World Journal of Agricultural Sciences 7(1):100-103.

Ismail, W. I. F. W and N. Ngadiman. (2017). Land Use Conversion on Rice Production: Policies, Rice Productivity and Paddy Landowners. International Journal of Real Estate Studies 11(2):33-39.

Kementerian Pertanian. (2015). Outlook Komoditas Pertanian Subsektor Tanaman Pangan. Pusat Data dan Sistem Informasi Pertanian Kementerian Pertanian. 
Merem, E. C., Y. Twumasi, J. Wesley, P. Isokpehi, M. Shenge, S. Fageir, M. Crisler, C. Romorno, A. Hines, G. Hirse, S. Ochai, S. Leggett, E. Nwagboso. (2017). Analyzing Rice Production Issues in the Niger State Area of Nigeria's Middle Belt. Food and Public Health 7(1):7-22.

Ministry of Public Works (2016). Available online at: http://sippa.ciptakarya.pu.go.id/sippa_online/ws_file/dokumen/rpi2jm/DOCRPIJM_1504 704048Bab4-Profil_KabKota_bdg.pdf. (accessed 5 April 2017).

Mundhe, F. 2015. Agricultural Productivity in India: Trends During Five Year Plans. The Business \& Management Review, 5(4):175-181.

Panuju, D. R., K. Mizuno and B. H. Trisasongko. (2013). The Dynamics of Rice Production in Indonesia 1961-2009. Journal of The Saudi Society of Agricultural Sciences 12:27-37.

Ray, D.K., J. S. Gerber, G. K. MacDonald and P. C. West. (2015). Climate Variation Explains a Third of Global Crop Yield Variability. Nature Communications 6(5989):1-9.

Roel, A. and R. E. Plant. Spatiotemporal Analysis of Rice Yield Variability in two California Fields. Agronomy Journal 96:77-90.

Singha, M., B. Wu and M. Zhang. (2017). Object-Based Paddy Rice Mapping Using HJ1A/B Data and Temporal Features Extracted from Time Series MODIS NDVI Data. Sensors 17(10):1-17.

Suarja, I G. (2015). Laporan Akhir Program Ayung Lestari di Desa Belok Sidan \& Plaga Kec. Petang, Kabupaten Badung. PT. Tirta Investama- Janma.

Subash, N. and B. Gangwar. (2014). Statistical Analysis of Indian Rainfall and Rice Productivity Anomalies Over The Last Decades. International Journal of Climatology 34:2378-2392.

Suharyanto, J. H. Mulyo, D. H. Darwanto and S. Widodo. (2015). Production and Efficiency Analysis of the Integrated Crop Management of Rice in Bali. Penelitian Pertanian Tanaman Pangan 34(2):131-144.

Takama, T., P. Setyani and E. Aldrian. (2014). Climate Change Vulnerability to Rice Paddy Production in Bali, Indonesia. In Handbook of Climate Change Adaptation, Eds., Filho, W. L. Springer-Verlag Berlin Heidelberg, pp: 1731-1757.

Talpur, M. A., J. I. Changying, S. A. Junejo and A. A. Tagar. (2013). Impact of Rice Crop on Soil Quality and Fertility. Bulgarian Journal of Agricultural Science 19(6):12871291.

Tripathi, R., A. K. Nayak, R. Raja, M. Shahid, A. Kumar, S. Mohanty, B. B. Panda, B. Lal and P. Gautam. (2014). Forecasting Rice Productivity and Production of Odisha, India, Using Autoregressive Integrated Moving Average Models, Eds., Tsadilas, C. Hindawi Publishing Corporation, pp:1-9.

Ustriyana, I N. G. (2015). Dynamic Modeling of Rice Stock in Bali Province, Indonesia. European Journal of Business and Management 7(26):173-180.

Wassmann, R., S. V. K. Jagadish, K. Sumfleth, H. Pathak, G. Howell, A. Ismail, R. Serraj, E. Redona, R. K. Singh, S. Heuer. (2009). Regional Vulnerability of Climate Change Impacts on Asian Rice Production and Scope for Adaptation. In Advances in Agronomy Vol. 102, Eds., Sparks, D.L. The Netherlands, Elsevier Inc., pp: 91-133. 